Proceedings of the New Zealand Grassland Association 46: 31-36 (1985)

\title{
FARM DESIGN FOR EFFICIENT IRRIGATION
}

A.R. TAYLOR, D.G. ALDRIDGE and I.M. KERMODE

Winchmore Irrigation Research Station, Ashburton

\section{Abstract}

The development of irrigation on farms in Mid Canterbury has generally been carried out on a paddock basis, as cheaply as possible and with little thought to farm design leading to systems which are labour intensive and do not use the water efficiently.

With increasing pressure on our water supplies and the need for farmers to irrigate extra land recent work has been directed towards increasing the efficiency of water useage.

It has been found that by increasing the flow of water down the strip from $180 / / \mathrm{s}$ to $300 / / \mathrm{s}$ that $11 \%$ extra land can be irrigated with the same volume of water, If the border-strip length is shortened from $300 \mathrm{~m}$ to 200 $\mathrm{m}$ the irrigation rate will increase from $0.73 \mathrm{ha} /$ hour to $0.91 \mathrm{ha} / \mathrm{hour}$ when using a flow of $230 \mathrm{l} / \mathrm{s}$ and a group of four strips. When the increased flow rate and the decreased strip length are combined there is a greater effect than when the two are applied independently.

With better layouts and increased watering efficiency greater areas of individual farms are being irrigated and the irrigation level is being reduced.

Keywords: Irrigation, border-strip, efficiency, farm irrigation

\section{INTRODUCTION}

In the 1860's water was not available on the plains between the rivers of Mid Canterbury. Efficient irrigation was problematic. In the 1880's there was a development of a stock water race system which made possible the division of the pastoral runs.

Irrigation had been discussed since early settlement and while some experimental work was carried out none of the early plans were ever implemented.

\section{RANGITATA DIVERSION RACE}

The Rangitata Diversion Race was designed in the mid 1930's and construction began in 1938. The concept was to take water from the Rangitata River and divert 30 $\mathrm{m}^{3} / \mathrm{s}$ into an open channel to flow across the top of the Plains at a contour of approximately $300 \mathrm{~m}$ and supply water to a number of irrigation schemes. Once it crossed the plains, siphoning under each of the rivers, it dropped down into the Rakaia, through the Highbank Power station generating $25 \mathrm{MW}$ of electricity, making it one of the first multiple use projects in the country. The 1939-45 war interrupted progress and eventually the opening took place in June 1945.

\section{ON FARM DEVELOPMENT}

The schemes were well designed and engineered to the farmer's gate but were really a water disposal system rather than an irrigation system. A plan of a typical 200 ha farm at that time is shown in fig. la. The farmer was given the water and it was up to him to use it even though he had no experience. Because of this lack of knowledge on the farmer's part the MWD (then the Public Works Department) was instructed to border just one hectare of land free of charge for each farmer, so that the farmer could see the value of border strip irrigation. This free bordering did not encourage large areas to come under construction as shown by the rate of development in fig. 2 which uses information from MWD construction teams. 

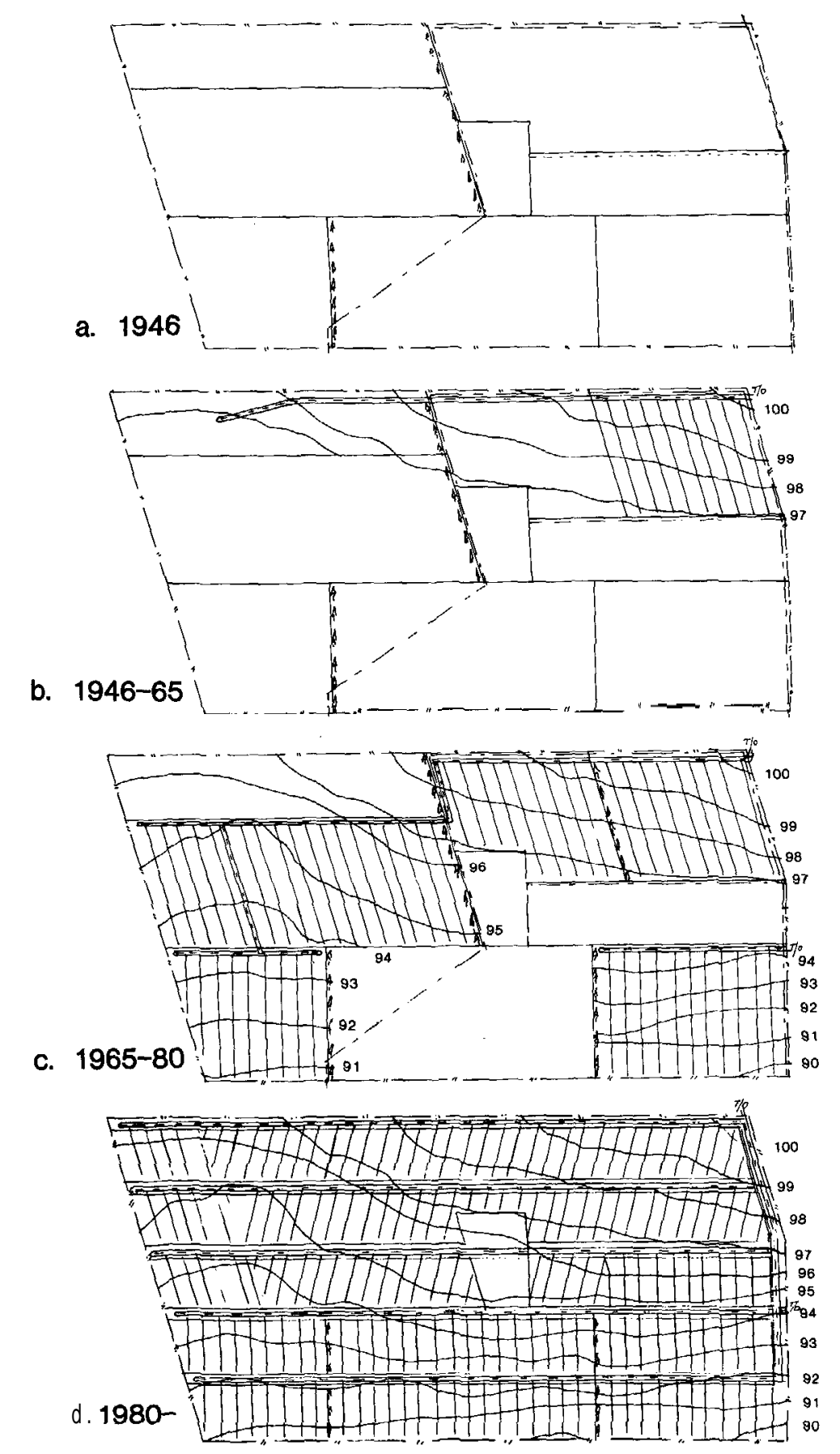

Figure 1: Model Ashburton-Lyndhurst farm. 


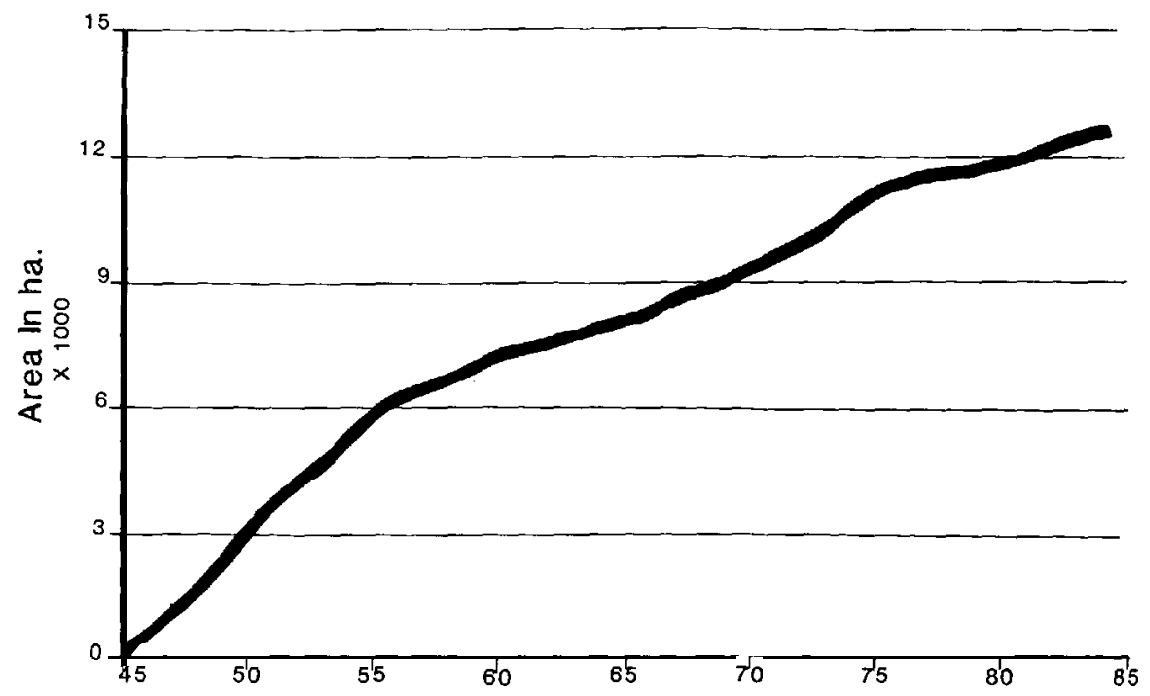

Time In Years

Figure 2: Border development in the Ashburton-Lyndhurst Irrigation Scheme

Farmers elected to develop their best paddocks with little thought or planning for water reticulation or labour efficiency. The MWD would carry out a contour survey of the paddock and draw a plan usually with the border strips directed down the steepest fall and a headrace up against the top fence lines, often along two fences. Headgates in the centre of each strip could be a board between two slotted concrete blocks or just an opening shovelled out of the bank. To irrigate, a triangular wooden frame covered with a sack or canvas sheet was placed in the race at the appropriate point and the total flow was directed down one strip. Although this may have resulted in a relatively efficient use of water it was very time consuming. For example, Lobb \& Hall (1963) show that although the irrigator was on site all the time he only worked for 65 minutes out of a total irrigating time of 261 minutes. With this largely unproductive labour input into irrigation most areas were sown to pasture and irrigation used as an insurance against summer drought. Development stopped when 30-40 ha had been provided with water (Fig. 1 b) as this was the upper limit one person could irrigate. As a consequence little or no thought was put into total farm design to try and save water and reduce labour.

The typical farm of 200 ha in the Ashburton-Lynhurst Scheme was entitled to 60 hrs of water a week delivered in flows of $230 / / \mathrm{s}$ and on a moving roster. It was thought that this would be enough to irrigate half the property. With piecemeal development, using water only 12 hours per day and long strip lengths, often greater than $400 \mathrm{~m}$, many farmers were only able to irrigate their 30-40 ha of pasture once every three to four weeks.

\section{AUTOMATIC IRRIGATION}

Up to the 1960's little if any experimentation had been carried out on land preparation. At Winchmore it had been found that with grouped headraces and alarm clock release units, labour input could be drastically reduced and the total farm could be designed for irrigation. This new approach worked well on an area where there had been no development, but in the Ashburton-Lyndhurst Scheme with its past 
piecemeal development, old irrigation races had to be modified to try to take advantage of the labour saving devices. The area of the scheme irrigated by the mid 1970's was just over 40\% (approximately 10,000 ha). Some farmers prepared 5/8's of their farm for border strip irrigation, a figure that was considered could be irrigated with the water supply available. This flow allowed $100 \mathrm{~mm}$ on 5/8's of the farm every 17.5 days. Development of the New Zealand automatic system is summarised in Table 1 (Taylor et a/ 1982). The last two columns have been calculated from the rate of irrigation and the flow delivered to the unit and show the average depth of water applied per irrigation.

Table 1: EFFECTS OF IRRIGATION SYSTEM IMPROVEMENTS ON LABOUR REQUIREMENTS AND IRRIGATION RATES. (Data from a 65 ha unit at WIRS).

\begin{tabular}{|c|c|c|c|c|c|c|c|}
\hline \multirow[b]{2}{*}{ Year } & \multirow[b]{2}{*}{ System } & \multicolumn{2}{|c|}{$\begin{array}{l}\text { Labour requirement } \\
\text { (min/ha) }\end{array}$} & \multicolumn{2}{|c|}{$\begin{array}{l}\text { Rate of Irrigation } \\
\text { (ha/day) }\end{array}$} & \multicolumn{2}{|c|}{$\begin{array}{l}\text { Depth applied } \\
\text { (mm) }\end{array}$} \\
\hline & & yearly & average & yearly & average & yearly & average \\
\hline Pre 1958 & Manual & $50-100$ & 90 & $7-14$ & $\begin{array}{c}8.3 \\
12 \mathrm{hr} \text { day }\end{array}$ & $142-71$ & 120 \\
\hline 1958159 & Downstream & 12.2 & & 14.3 & & 139 & \\
\hline 1959160 & Canvas & 7.8 & 8.2 & 16.9 & 16.7 & 118 & 119 \\
\hline $\begin{array}{l}1960 / 61 \\
1961 / 62\end{array}$ & & $\begin{array}{l}6.7 \\
6.2\end{array}$ & & $\begin{array}{l}18.1 \\
17.6\end{array}$ & & $\begin{array}{l}110 \\
113\end{array}$ & \\
\hline $1962 / 63$ & Upstream & 4.9 & & 19.6 & & 101 & \\
\hline $\begin{array}{l}1963 / 64 \\
1964165\end{array}$ & Canvas & $\begin{array}{l}4.2 \\
4.3\end{array}$ & 4.5 & $\begin{array}{l}21.6 \\
22.2\end{array}$ & 21.1 & $\begin{array}{l}92 \\
90\end{array}$ & 94 \\
\hline $\begin{array}{l}1965 / 66 \\
1966 / 67\end{array}$ & $\begin{array}{l}\text { Upstream } \\
\text { Concrete }\end{array}$ & $\begin{array}{l}3.2 \\
3.0\end{array}$ & & $\begin{array}{l}25.5 \\
24.5\end{array}$ & & $\begin{array}{l}78 \\
81\end{array}$ & \\
\hline 1967168 & & 2.8 & 3.0 & 23.7 & 24.6 & 84 & 81 \\
\hline 1968169 & & 2.9 & & 24.8 & & 80 & \\
\hline $1969 / 70$ & & 3.0 & & 24.5 & & 81 & \\
\hline 1970171 & & 2.9 & & 24.7 & & 80 & \\
\hline
\end{tabular}

Note: Preset equipment was used after 1958.

\section{CHANGE TO CROPPING}

Some farmers were able to develop up to $100 \%$ of their farm for irrigation by reducing stock and going into a mixed cropping enterprise. They were able to do this in the knowledge that the seasonal water demand for crop and pasture could be manipulated so that each would receive water at the most critical time but each may be a little short at other times. The development that had taken place is shown in figure Ic. In the last few years with decreased returns from sheep farming there has been an even greater increase in cropping, as well as a move into dairying and deer farming. All these farming systems put more pressure on the water supply especially when an area greater than $5 / 8$ 's of the farm is developed.

Recent studies carried out at Winchmore have been directed towards the more efficient use of water on the farm. Design standards of the 1960's and 70's are now unacceptable. In the 1980's the aim is towards total farm irrigation for high production, using the same, or a lesser amount of water that is available from the resource. 


\section{FARM IRRIGATION}

Data, collected from single border strips (Taylor 1981) showed that greater efficiency of water could be attained if (a), a steady flow was supplied to the land, and (b), a flow of not less than $60 \mathrm{l} / \mathrm{s}$ were applied to a $12 \mathrm{~m}$ wide strip. Other things which affected the efficiency were antecedent soil moisture, slope of the land, and height of pasture.

To test the effect on a farm scale, a joint project between Lincoln College, MWD and MAF was established. A farm was selected and measurements were made of the flow of water delivered to the farm, the rate that the water advanced down the strip, the soil moisture, the pasture or crop height and the slope of the strips. With this data it was possible to calculate the average depth of water supplied to each strip as well as the effect of antecedent soil moisture and pasture height on the depth applied. The average flow though the farm turnout was below the designed unit flow of $230 / / \mathrm{s}$ and that it varied (sometimes in a matter of minutes) from $120 / / \mathrm{s}$ to $190 / / \mathrm{s}$. In the first season a pump was used to overcome this variation in flow, enabling the testing of flows of up to $335 \mathrm{~J} / \mathrm{s}$.

During the following winter (1982) a new type of turnout was designed, constructed and installed (fig. 3). The "bladder valve" as it became known, enabled a constant flow rate to be delivered to the farm for each irrigation, only varying 1 or 2 //s about the mean. It also allowed different flows to be delivered at different times.

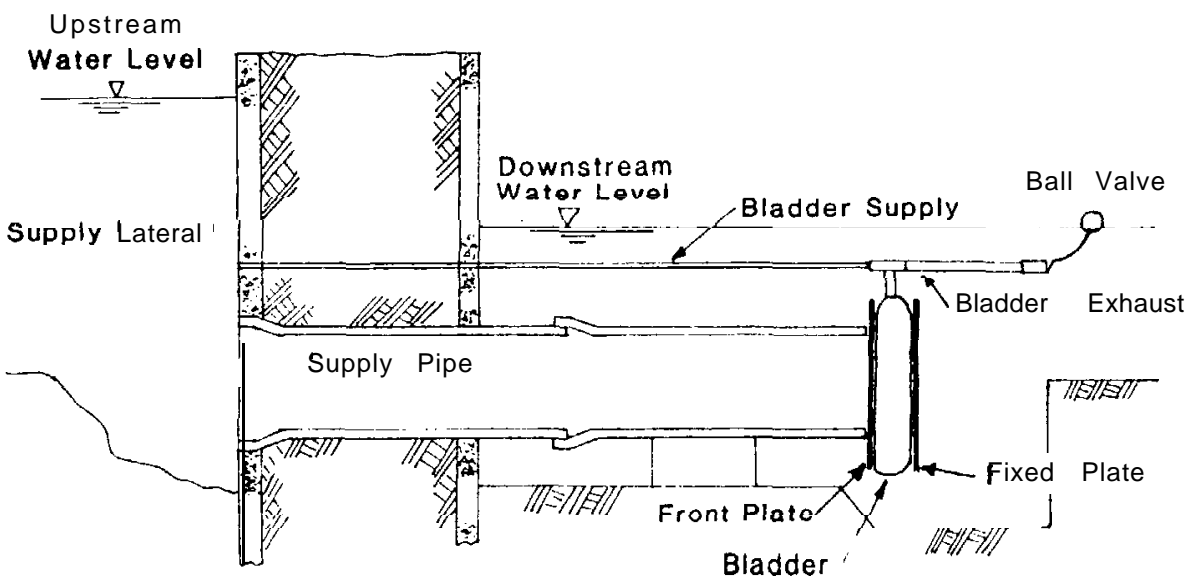

Figure 3: A schematic view of the bladder valve.

With a constant supply of water to the farm, the most efficient means of application to the border strips was investigated. A range of flows were tested, the rate of water advance down the strip measured and the area irrigated per unit of time was calculated. Over the range of data collected the most significant relationship developed was the following equation.

where $\mathbf{R}=$ rate of irrigation (ha/hr)

$$
R=0.001 Q^{1 \cdot 21}
$$

$\mathbf{Q}=$ water flow to groups $(/ / \mathbf{s})$

From equation (1) and the flow rate, the average depth applied to the area irrigated can be calculated (Table 2). The average border strip length varied from 250 $\mathrm{m}$ to $300 \mathrm{~m}$ and there were usually 4 per group.

These results indicate that if the unit flow to the farm was increased from $180 \mathrm{l} / \mathrm{s}$ to $300 / / \mathrm{s}$ then the average depth applied at each irrigation could be reduced by $11 \%$. 
Table 2: VARIATION IN AVERAGE DEPTH APPLIED WITH DIFFERENT FLOWS

\begin{tabular}{ccc}
\hline $\begin{array}{c}\text { Flow } \\
\text { (L/s) }\end{array}$ & $\begin{array}{c}\text { Irrigation Rate } \\
\text { (ha/hr) }\end{array}$ & $\begin{array}{c}\text { Average depth applied } \\
(\mathbf{m m})\end{array}$ \\
\hline 100 & 0.263 & 137 \\
150 & 0.430 & 126 \\
$180^{*}$ & 0.536 & 121 \\
200 & 0.608 & 118 \\
250 & 0.797 & 113 \\
300 & 0.994 & 109 \\
350 & 1.198 & 105 \\
\hline
\end{tabular}

*average flow to farm before the installation of the bladder valve

This means that either a greater area could be irrigated or that the return interval between irrigations could be reduced. Taylor (1975) showed that by decreasing the length of the strip a large saving could be made in the volume of water applied per ha. For example when using a flow of 60 //s down a $12 \mathrm{~m}$ wide strip the average depth applied was $161 \mathrm{~mm}, 98 \mathrm{~mm}$ and $84 \mathrm{~mm}$ for $440 \mathrm{~m}, 220 \mathrm{~m}$ and $110 \mathrm{~m}$ long strips respectively. This is the same as an irrigation rate of $0.54 \mathrm{halhr}, 0.88 \mathrm{ha} / \mathrm{ha}$ and 1.02 halhr for the three strip lengths. He also showed that there was a substantial difference between using a flow of $30 / / \mathrm{s}$ and $60 \mathrm{l} / \mathrm{s}$ down one strip but very little when using a flow greater than $60 \mathrm{l} / \mathrm{s}$.

\section{IMPLICATIONS FOR IRRIGATION FARM}

In the Ashburton-Lyndhurst Irrigation Scheme we must construct border-strips which are not greater than $200 \mathrm{~m}$ long. Flows of greater than $60 \mathrm{l} / \mathrm{s}$ must be applied to each $12 \mathrm{~m}$ wide strip. This means that to take advantage of the labour saving automatic irrigation system and to have high efficiency a farm supply of $300 \mathrm{~N} / \mathrm{s}$ or greater should be considered. These criteria are used in Fig. 1d which shows the changes that must be made to the 200 ha farm to bring it up to the requirement of the 1980's.

\section{REFERENCES}

Lobb, W.R.; Hall, A.D. 1963. N.Z. J. Agric 106: 318-327.

Taylor, A.R., Ryde, D.H., Aldridge, D.G. 1982. Trans ASAE 25(1): 120-123, 129.

1975. Proc. NZ Gass/d Ass. 36 (1): 30-38.

1981. PhD thesis, University of Canterbury. 229 pp. 